\title{
A STUDY ON THE MONTHLY TAX DEDUCTION AS THE FINAL TAX AMONGST MALAYSIAN SALARIED TAXPAYERS: THEORY OF PLANNED BEHAVIOUR APPROACH
}

\author{
Zainol Bidin ${ }^{1}$ \\ Tunku Puteri Intan Safinaz School of Accountancy (TISSA-UUM), Malaysia. \\ (Email: b.zainol@uum.edu.my) \\ Idawati Ibrahim*2 \\ Tunku Puteri Intan Safinaz School of Accountancy (TISSA-UUM), Malaysia. \\ (Email: idawati@uum.edu.my) \\ Tel.: +6-012-6594828; Fax: +6-04-9287216 \\ Natrah Saad ${ }^{3}$ \\ Tunku Puteri Intan Safinaz School of Accountancy (TISSA-UUM), Malaysia. \\ (Email: natrah@uum.edu.my) \\ Muzainah Mansor ${ }^{4}$ \\ Tunku Puteri Intan Safinaz School of Accountancy (TISSA-UUM), Malaysia. \\ (Email: muzainah@uum.edu.my)
}

Received date: 12-11-2019

Revised date: 17-11-2019

Accepted date: 19-11-2019

Published date: 15-12-2019

To cite this document: Bidin, Z., Ibrahim, I., Saad, N., \& Mansor, M. (2019). A Study on The Monthly Tax Deduction as The Final Tax amongst Malaysian Salaried Taxpayers: Theory of Planned Behaviour Approach. Advanced International Journal of Banking, Accounting and Finance, 1 (1), 36-47.

DOI: $10.35631 /$ aijbaf.11004

\begin{abstract}
This study provides empirical evidence related to the effect of some factors towards the acceptance of the Monthly Tax Deduction (MTD) as the final tax. The MTD system is referred to as a no-return system. The purpose of such a system is mainly to reduce taxpayers' burden and reduce tax evasion as well as increase tax collection. In Malaysia, the MTD as the final tax scheme for the salaried group of taxpayers is still new. Thus, the purpose of this study has been to determine the acceptance of the MTD as the final tax with the perspective of the theory of planned behaviour. Using the theory of planned behaviour (TPB) as the basis of this study's framework, the useable data were collected from 150 salaried earners from Petronas Berhad and Inland Revenue Board of Malaysia. The data were analysed using SPSS. The findings from the multiple regression analysis revealed that attitude, subjective norms, and perceived behavioural control had significant positive effects on the Intention to accept the MTD as the final tax, whilst readiness was insignificant. Moreover, the results also indicated that attitude was the most influential factor. This study confirms the applicability of the TPB in the intention to accept the MTD as the final tax. The findings on the usage intention towards the MTD as the final tax and its determinants will also assist the IRBM in formulating strategies
\end{abstract}


or mechanisms for improvement. Implications and recommendations for policymakers are also discussed.

Keywords: Monthly Tax Deduction, Personal Income Tax, Theory of Planned Behaviour

\section{Introduction}

The majority of taxpayers in many countries, such as in Europe and Australia, do not need to prepare their own income tax returns because their tax authorities have generated the returns for them. In countries like the United Kingdom (U.K.) and New Zealand, personal taxpayers do not have to file an income tax return due to a good withholding system at the source (Evans, 2004). In a few other Scandinavia countries like Denmark, taxpayers only need to check and verify the tax returns prepared by the revenue body (OECD, 2006). The system is called a prefilled return system. The purpose of such systems is to reduce taxpayers' burdens and at the same time reduce tax evasion as well as increase revenue collection by maximising the use of technology (Ibrahim \& Pope, 2011). In Malaysia, the Inland Revenue Board of Malaysia (IRBM) has introduced the Monthly Tax Deduction (MTD) as the final tax since the year 2014. This system is mainly to assist the salaried taxpayers' group. Although most salaried taxpayers viewed completing the income tax form as being easy (Saad, 2011), some taxpayers still did not file the return forms simply because they had a belief that it was not necessary as their incomes had been deducted at the source through the MTD system. Whilst this has long been applicable in overseas countries, such as the UK and New Zealand, the practice had not been implemented in Malaysia until 2014. In other words, their misconceptions have led to unintentional non-compliance, which has, consequently, affected the loss in tax revenue collection.

The implementation of the MTD as the final tax has deemed timely and relevant considering the contribution of personal income tax (PIT) to the country's economic growth. The collection from the PIT in Malaysia had been ranked as the third major contributor after corporate and petroleum taxes for 2014 and up to second place in 2015 and 2016. As for 2016, the collection from the PIT was a bit higher (RM29, 602 million) which contributed to almost $26 \%$ of the total direct tax collection (IRBM, $(2015,2016))$.

In addition, in terms of the number of taxpayers, it was reported that the total number of registered personal taxpayers and partnerships for the year 2016 amounted to more than 8 million registrants or about $82 \%$ of the total number of registered taxpayers (IRBM, 2016). This indicates that tax collection from personal taxpayers cannot be ignored due to the importance of the contribution from personal taxpayers and, specifically, from the MTD collection. Theoretically, this study extends the well-established Theory of Planned Behaviour (TPB) by integrating a new variable, i.e., readiness. Thus, the objective of this study has been to examine the relationships between readiness, attitude, subjective norms, perceived behavioural control and intention of accepting the MTD as the final tax. Furthermore, to the researchers' knowledge, this is the first attempt made to employ the TPB in the MTD. Practically, the results of this study will provide insights to the IRBM on the readiness of the employers in implementing the MTD as the final tax. Equally important, the findings on the acceptance of the taxpayers towards the MTD as the final tax and its determinants will also assist the IRBM in improving the strategies/mechanisms for improvement. The next section discusses the literature about the MTD as the final tax, the theory of reasoned action, and its variables. 


\section{Literature Review}

\section{Theory of Planned Behaviour}

The Theory of Planned Behaviour (TPB) is a widely used theory to explain the relationship between perception and behaviour in various disciplines (Ajzen, 1991). It is an extended Theory of Reasoned Action developed by Fishbein and Ajzen (1975), which provides better explanatory power for behavioral (Ajzen, 1991; Maden, Ellen \& Ajzen, 1992). According to the TPB, intention is determined by three factors, i.e., attitude, subjective norms, and perceived behavioural control; whilst intention is the immediate determinant of one's behaviour. Despite being an established theory, many previous studies have extended the TPB to suit their objectives and improve the explanatory power of the models (Javadi, et al., 2012; Carswell \&Venkatesh, 2002; Wu \& Chen, 2005). Consistent with their studies, the present study has extended the TPB by integrating employers' readiness as an independent variable.

An individual's actual behaviour in performing certain actions is directly influenced by his or her intention. Instead, the intention to accept the MTD as the final tax is considered as a proxy for the actual behaviour. Intention is a course of action that one proposes to follow (Moorthy, et al., 2014). In this study, intention posits one's desire to accept the MTD as the final tax and is used as a proxy for the actual behaviour. In other words, the intention to accept the MTD as the final tax would act as a final dependent variable. This is common in the TPB as it is assumed that intention captures the motivational factors that influence behaviour (Ajzen, 1991, p.181). Implicitly, the stronger the intention to accept the MTD as the final tax, the more likely the individual is to actually accept the MTD as the final tax. The positive association between intention and actual behavior is confirmed by Venkatesh and Davis (2000) and Venkatesh and Morris (2000).

Attitude stands to be a crucial factor in shaping individuals' behaviours (Ajzen, 1991 and Fishbein and Ajzen, 1975). Attitude refers to the positive and negative evaluation for selfperformance of a particular behaviour (Lu, Huang \& Lo, 2010). In this context, attitude denotes the favourable and unfavourable evaluations of the MTD as the final tax. Specifically, if one favours the MTD as the final tax, it will influence his or her willingness to employ such behaviour and vice versa. A positive relationship between attitude and intention has been documented in previous studies across disciplines. Most of the studies reported a positive influence of attitude. Specifically, Bidin and Shamsudin (2014) investigated the influence of attitudes on the intention to comply with the GST amongst individual taxpayers. The study found a positive significant relationship between attitude and intention. Saad (2011) addressed the role of attitudes on the intention to comply with income tax amongst salaried taxpayers. The study showed that the attitudes of the salaried taxpayers had a positive influence on their intentions to comply. Bidin, Shamsudin, Shalihen, and Zainudin (2011) focused on the influence of attitude on behavioural intentions to comply with local sales tax amongst local sales agents. The study found a significant positive relationship between attitude and intention. Andi, Sutrisno, Rosidi, \& Roekhudin (2018) have proved empirically that attitudes have positive influence on intentions. Moreover, based on experimental settings, Bobek and Hatfield (2003) explored the attitude variable and reported that there was a significant relationship between attitude and tax compliance behaviour. Based on the above discussions, the following hypothesis was formulated:

H1: Attitudes have positive effects on the intentions to accept the MTD as the final tax. 
Subjective norms is the second factor established by both the TRA and TPB to be an important variable that plays a central role in explaining an individual's behaviour. Subjective norms refers to the individual's perception about his or her important referents (such as spouse, colleagues or parents) that he or she should or should not engage in a behaviour(Ajzen, 1991; Fishbein \& Ajzen, 1975). In the context of this study, subjective norms involved the impacts of referent groups that influence an employee to accept or reject the MTD as the final tax. Prior studies in various fields have documented evidence on the influence of subjective norms as a central factor that determines the intention to engage in a behaviour (Alam \& Sayuti, 2011; Azman \& Bidin, 2015; Bidin, et al., 2009; Bidin \& Shamsudin, 2014; Blanchard, et al., 2002; Bobek, Hatfield, \& Wentzel, 2007; Chatzisarantis \& Hagger, 2005; Kalafatis, et al., 1999; Kolvereid \& Isaksen, 2006; and Krueger \& Carsrud, 1993). As mentioned earlier in the case of attitudes, the research on subjective norms about tax and Zakah that relate to an individual's income may be more relevant for developing a model for the MTD. This is because, tax and Zakah involve accepting to give out part of one's earnings as a levy as in the case of the MTD. Past studies reported that there were significant relationships between subjective norms and behaviour. Bobek and Hatfield (2003) reported a significant effect of subjective norms on the tax compliance behaviour amongst individual US taxpayers. Andi, et al. (2018) reported that subjective norms have a positive influence on intention. Saad (2011) focused on the Malaysian salaried taxpayers' compliance behaviours and found a significant relationship between subjective norms and compliance behaviour. Bidin, et al. (2011) decomposed subjective norms into primary and secondary normative beliefs. The primary subjective norms involve the influence of the tax agent of a company, whilst the secondary normative belief consists of friends or associates of tax payers who are given the task to manage sales tax related matters in other companies. Bidin and Shamsudin (2014) focused on the influence of subjective norms on the intention to comply with the GST amongst individual taxpayers. The study reported that there was significant influence by subjective norms on the intention to comply with the GST. Moreover, Azman and Bidin (2015) investigated the influence of referent groups of individuals paying Zakah on their savings on their compliance behaviour. The study found that referent group significantly influence the Zakah compliance behaviour on savings. Based on the above discussion, the second hypothesis was formulated as follows:

H2: Subjective norms have positive effects on the intentions to accept the MTD as the final tax.

Perceived behavioural control (PBC) refers to an individual's perceived ease or difficulty to perform a particular behaviour (Lu, Huang, \& Lo, 2010). Even though an individual has positive attitudes towards a given behaviour and encouragement from others to perform such a behaviour, the ability to engage in such a behaviour is another important component to performing the behaviour. Thus, the TPB refers to the perception of ease or difficulty of engaging in a behaviour of interest by an individual. In the context of this study, perceived behavioural control refers to the MTD filers' perceptions of ease or difficulty in accepting the MTD as the final tax. Also, several studies have provided evidence on the relationship between the PBC and behavioural intention or the behaviour in different fields (Bidin, et al., 2011; Blanchard, et al., 2002; Bobek \& Hatfield, 2003; Kalafatis, et al., 1999; and Nishimura \& Tristan, 2011). More pertinent to this study, studies on tax and Zakah have been considered in this review. Based on the TPB, Bobek and Hatfield (2003) argued that, the PBC in the case of tax compliance behaviour is not all about the perception of the ease or difficulty to engage in non-compliance behaviours. Rather, it has more to do with the degree of control the individual has to carry out the behaviour. Bidin, et al. (2011) reported significant influence of the TPB on the intention to pay sales tax amongst local sales agents. Azman and Bidin (2015) focused on 
individual savings Zakah compliance. The study found that the PBC has a significant effect on the Zakah compliance behaviour on savings. Based on the above literature, it was hypothesised that:

$\mathrm{H}_{3}$ : Perceived behavioural control has a positive effect on the intention to accept the MTD as the final tax.

Readiness to change stands as an important element for both individuals and organisations to thrive in the contemporary era of global competition (Armenakis, Harris, \& Mossholder, 1993). Many studies have observed that recipients' reactions to change play a vital role in its potential success (Bartunek, Rousseau, Rudolph, \& DePalma, 2006; Vakola, 2013). Hence, understanding the readiness for change of an organisation and its employees is crucial for a successful change in the organisation (Mueller, Jenny, \& Bauer, 2012). In their review of the concept of readiness in organisational change literature, Mueller, et al. (2012) identified readiness as a multifaceted concept involving: (1) Individual employee's readiness to change as the confidence in his or her abilities, (2) Perception about organisational readiness to change involves confidence in the ability of the organisation to manage the change, and (3) Actual organisational readiness to change involving the ability to implement the change by the organisation. This study has been concerned with the employees' perceived organisational readiness to change and their confidence in the organisation's ability to manage the MTD as the final tax. For example, an employee may be more likely to accept the MTD as the final tax, if he or she has a positive perception that his/her organisation is ready and capable of implementing the MTD as the final tax. Thus, it is expected that the perceived actions of the organisation to implement the new system may have a direct impact on the employees' intentions to accept the new system. Several studies have established that there is a connection between readiness and behaviour. More relevant to the current study, in the literature of organisational change, Schneider and Bowen (1993) established that there was a positive relationship between the perception of good practices and procedures in place to support service delivery and customers' good service experience in the banking industry. This shows the reflection of the internal organisational climate on the employees' behaviours (of deliver good services). This finding is consistent with Johnson (1996) and Schneider and Bowen (1985). Bettencourt and Brown (2003) reported significant influence of organisational commitment on the external representation and internal influence behaviours. The point here is that, employees' perceptions about their organisation's readiness to change reflects on their behaviours (Vakola, 2013). In tax compliance studies, Hadi and Safizal (2016) found a significant influence of readiness issues on acceptance and compliance with the GST in Malaysia. Based on the TPB, Cheon, et al. (2012) reported a significant effect of instructor's readiness on intention (through subjective norms) to accept mobile learning amongst college students. Based on the above literature, it was hypothesised that:

$\mathrm{H}_{4}$ : Readiness has a positive effect on the intention to accept the MTD as the final tax.

\section{Methodology}

The research framework as shown in Figure 1 was based on the TPB which consists of attitude, subjective norms, perceived behavioural control, and employers' readiness as independent variables and Intention to use the MTD as the final tax as the dependent variable. 


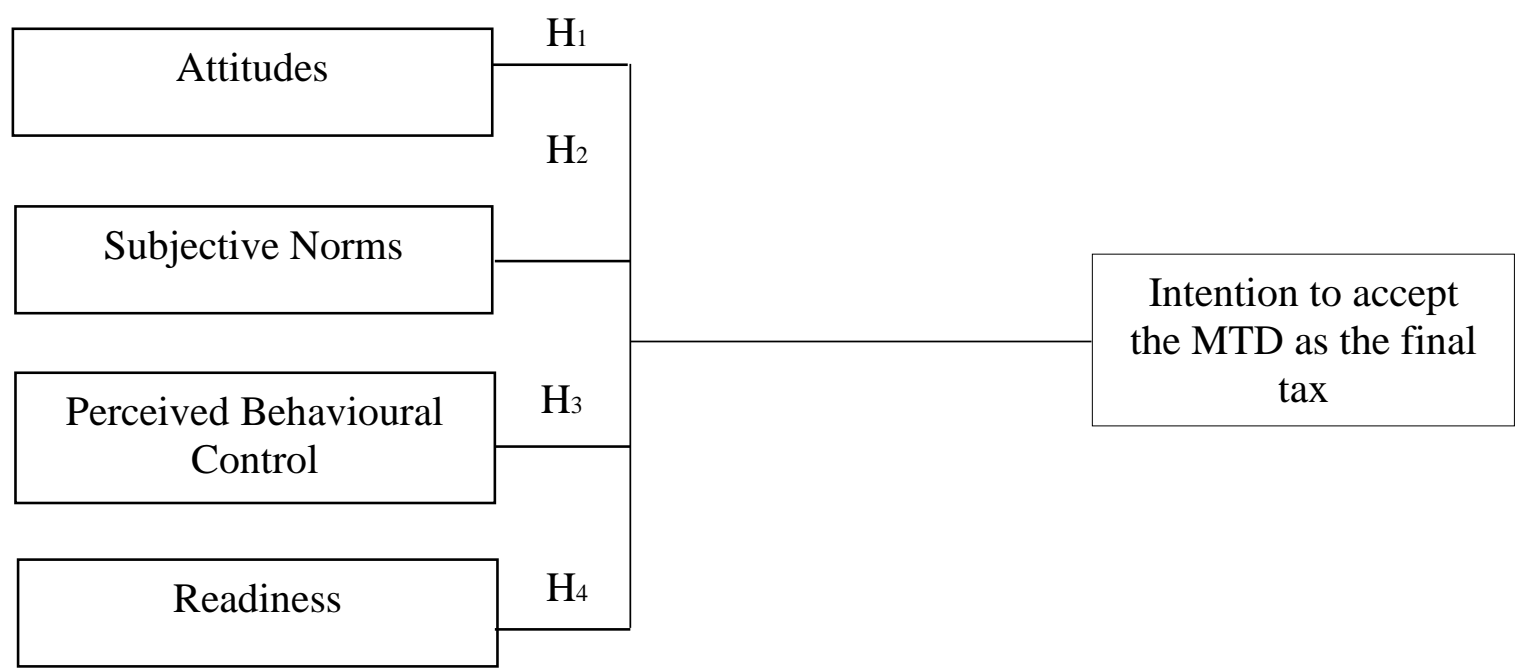

Figure 1. Research Framework

The respondents for this study were comprised of the employees at the IRBM and Petronas Berhad. These two organisations were chosen for this study as they were selected by the tax authority to exercise the MTD as the final tax when it was first introduced (Ibrahim \& Pope, 2011). The survey of this study was carried out by using a structured questionnaire adapted from previous studies in the field of taxation. The survey were distributed in 2017 and the total number of surveys distributed were 200. The number was considered appropriate for statistical purposes as suggested by Hair (1998). The appropriate sample size for generalisation purposes is 15 to 20 for each variable. The data analyses conducted for this study were comprised of a descriptive analysis and multiple regression analysis using the SPSS software. All the constructs tested were measured using a 5-point Likert scale, ranging from $1=$ strongly disagree to $5=$ strongly agree. Three statements were developed to measure each construct.

\section{Findings}

\section{Descriptive Results}

The descriptive results indicated that the means for each variable were below 3 accept for the perceived behavioural control, which was slightly above 3. The results indicated that on average, the respondents had somewhat negative attitudes towards the MTD as the final tax. The respondents also disagreed that their peers and family had influenced their decisions towards the MTD as the final tax and, lastly, their average intention also indicated that they did not have a strong intention towards the MTD as the final tax. Table 1 depicts the results of the descriptive statistics for attitude, subjective norms, perceived behavioural control, readiness, and intention.

Table 1: Descriptive analysis according to the variables $(n=150)$.

\begin{tabular}{lcccc}
\hline \multicolumn{1}{c}{ Variables } & Minimum & Maximum & Mean & Standard Deviation \\
\hline Attitude & 1 & 5 & 2.700 & 1.167 \\
Subjective Norms & 1 & 5 & 2.776 & 1.006 \\
Perceived Behavioural Control & 1 & 5 & 3.320 & 1.198 \\
Readiness & 1 & 5 & 2.730 & 1.323 \\
Intention & 1 & 5 & 2.656 & 1.283 \\
\hline
\end{tabular}




\section{Pre-Analysis Results}

The data gathered has been tested for normality, reliability, validity, and multicollinearity problems. The results from the relevant analyses indicated that the study data was normally distributed with the skewness and kurtosis data being according to the suggestion by Hair, et al. (1998). Hair, et al. (1998) stated that the commonly used critical values for skewness and kurtosis are \pm 1.96 (for a .05 significant level) and \pm 2.58 (for a .01 significant level).

The reliability analysis using Cronbach's Alpha value showed that the values for all the variables were between 0.649 and 0.955 , which meant that all were good reliability values (Hair, et al.,1998). Table 2 shows the details.

Table 2: Reliability Test (n=150)

\begin{tabular}{lcc}
\hline \multicolumn{1}{c}{ Variables } & No. of Items & Cronbach's Alpha \\
\hline Attitude & 3 & 0.845 \\
Subjective norms & 3 & 0.878 \\
Perceived behavioural Control & 4 & 0.673 \\
Readiness & 2 & 0.649 \\
Intention & 3 & 0.955 \\
\hline
\end{tabular}

The factor analysis is used to perform the validity test. In this study, the PCA with varimax rotation was used on all the items in each variable. The results indicated that the KMO values for all the variables exceeded the threshold value of 0.70 which showed good results for validity (Hair, et al., 1998). Moreover, the BTOS showed that all the variables were significant with pvalues of 0.000 . Table 3 indicates the KMO and BTOS values.

Table 3: Factor Analysis $(\mathbf{n}=150)$

\begin{tabular}{lccc}
\hline \multicolumn{1}{c}{ Construct } & Number of Items & KMO & $\begin{array}{c}\text { BTOS } \\
\text { p-value }\end{array}$ \\
\hline Attitude & 3 & 0.655 & 0.000 \\
Subjective Norms & 3 & 0.694 & 0.000 \\
Perceived Behavioural Control & 4 & 0.631 & 0.000 \\
Readiness & 2 & 0.500 & 0.000 \\
Intention & 3 & 0.778 & 0.000 \\
\hline
\end{tabular}

Note: KMO = Kaiser-Meyer-Olkin; BTOS = Bartlett's Test of Sphericity

In this study, Pearson's correlation analysis was employed to analyse the data for the purpose of understanding the sample characteristics and levels of correlation amongst the variables. The results are presented below in Table 4. Cohen (1988) indicated the values of the correlation coefficients in the range of 0.10 to 0.29 as (weak), 0.30 to 0.49 as (medium), and 0.50 to 1.00 as (strong). Multicollinearity problems can also be identified with the correlation analysis. In this study, the results for the correlation were below 0.80 . These showed that there were no crucial multicollinearity problems (Hair, et al., 1998). 
Table 4: Pearson's Correlation Coefficient Analysis $(n=150)$

\begin{tabular}{cccccc}
\hline & ATT & SN & PBC & READ & INT \\
\hline ATT & 1.000 & & & & \\
SN & $0.503^{* *}$ & 1.000 & & & \\
PBC & $0.588^{* *}$ & $0.544^{* *}$ & 1.000 & & \\
READ & $0.185^{* *}$ & $0.520^{* *}$ & $0.304^{* *}$ & 1.000 & \\
INT & $0.742^{* *}$ & $0.720^{* *}$ & $0.726^{* *}$ & $0.347^{* *}$ & 1.000 \\
\hline
\end{tabular}

** Correlation is significant at the 0.01 level (2-tailed)

\section{Multiple Regression Results}

The result of the adjusted $\mathrm{R}$ square of $75.8 \%$ indicated that the determinants used in the model were able to explain about $76 \%$ of the factors that determined the intention to use the MTD as the final tax. As the percentage is considered good in social science studies, this also implies that the TPB is a good theory to predict the intention to accept the MTD as the final tax case amongst the salaried taxpayers. In Table 5, the results of the multiple regression analysis indicated that attitude, subjective norms, and perceived behavioural control had significant positive relationships with the intention to accept the MTD as the final $\operatorname{tax}(\mathrm{p}<0.001)$ whilst readiness was insignificant. Therefore, this study failed to reject $\mathrm{H}_{1}, \mathrm{H}_{2}$, and $\mathrm{H}_{3}$, which were developed earlier. In comparing the contribution of each predictor, the Beta values under the unstandardised coefficients indicated that attitude made the strongest unique contribution (0.729) to explaining the Intention to use the MTD as the final tax. The Beta value for subjective norms and perceived behavioural control were slightly lower, 0.466 and 0.338 , respectively.

Table 5: Regression of Attitude, Subjective Norms, Perceived behavioural control, and Readiness towards Intention $(n=150)$

\begin{tabular}{lrccccc}
\hline & \multicolumn{2}{c}{$\begin{array}{c}\text { Unstandardised } \\
\text { Coefficients }\end{array}$} & $\begin{array}{c}\text { Standardised } \\
\text { Coefficients }\end{array}$ & & \\
\cline { 2 - 4 } & B & Std. Error & Beta & t & Sig. \\
\hline Constant & -0.6703 & .985 & & & -6.081 & $.000^{*}$ \\
Attitude & .729 & .100 & .379 & 7.260 & $.000^{*}$ \\
Subjective norms & .466 & .072 & .365 & 6.510 & $.000^{*}$ \\
Perceived behavioural control & .338 & .059 & .307 & 5.732 & $.000^{*}$ \\
Readiness & .010 & 0.080 & 0.06 & 0.128 & .8890
\end{tabular}

Note: $* \mathrm{p}<0.001$, adjusted R Square $=0.758, \mathrm{~F}$-statistic $=117.651$, Sig. at 0.000

\section{Discussion and Conclusion}

The study extends the theory of planned behaviour in the field of taxation. Thus, the objective of this study was to investigate the relationships between attitude, subjective norms, perceived behavioural control, and the readiness with the intention to accept the MTD as the final tax. Using the multiple regression analysis, the results of the study indicated that the variables, namely, attitude, subjective norms, and perceived behavioural control, were able to significantly influence the intention to use the MTD as the final tax. Generally, the study demonstrated that the attitude, subjective norms, and perceived behavioural control variables are considered important factors in improving the compliance intention of the taxpayers. Meanwhile, the readiness variable towards the compliance intention is not an important factor in improving the compliance behaviour intention of the taxpayers. 
The significant relationship between attitude and intention to accept the MTD as the final tax is consistent with previous studies (Andi, et al. 2018; Bidin, et al. 2011). It is suggested for the tax authority to increase the advertisements and education towards the MTD as the final tax amongst the salaried taxpayers so that they can create more awareness and ultimately increase the internal motivation (in this case, the attitude) to accept the MTD as the final tax in the future. Implementing better strategies is crucial to reduce the compliance costs of many salaried taxpayers and free them from unnecessary vexation when filing the income tax returns. The study found that subjective norms significantly affected the compliance behaviour intention. The results of this study support previous research works (Azman \& Bidin, 2015; Bidin, et al., 2009; Bidin \& Shamsudin, 2014; and Bobek \& Hatfield, 2003). The subjective norms is an important factor in improving the intention to behave compliantly. This finding suggests that there is a certain role of referent groups, such as colleagues, tax officers, and employers, which may encourage taxpayers to comply with the tax.

The study also found that perceived behavioural control significantly affected the intention to accept the MTD as the final tax. Perceived behavioural control is also an important factor in improving the compliance behaviour intention amongst the taxpayers. The result supports the empirical studies of previous research (Bidin, et al., 2011; Blanchard, et al., 2002; and Bobek $\&$ Hatfield, 2003). This suggests that when a taxpayer has self-confidence in the MTD as the final tax, there is a possibility that there will be a high intention to accept the system.

The readiness variables towards compliance intention (intention to accept the MTD as the final tax) was found to not be significant. The results of this study cannot support the views, either theoretically or empirically from the results of the previous studies.In addition, it is also suggested that the tax authority improvised the MTD as the final tax scheme as currently the results indicate that taxpayers have low interests towards the scheme. This is probably due to the fact that under the current situation, normally the MTD is more than the final tax payable. Practices by other countries, such as Australia, Denmark or the UK, on the personal income tax may be studied in order to strengthen the current MTD as the final tax scheme. In order to develop a better attitude, subjective norms, and perceived behavioural control variables amongst the salary group, the government needs to continually provide information, education, and knowledge relating to the MTD, as a positive attitude would encourage better acceptance of the MTD as the final tax.

Some limitations also exist in this study. Although the current study is very limited in terms of factors tested and scope of respondents, it has shed some light on the acceptance of taxpayers on this new MTD as the final tax scheme. Future studies may expand the scope of the respondents to include other public and private institutions as the scheme now has been introduced for more than three years. It is also suggested to include other variables (i.e., awareness and knowledge) to the model being tested in this study to delve into a better understanding on the factors influencing the taxpayers' behaviours. This would provide the government with better input on how to ensure that the taxpayers are willing to accept the MTD as the final tax.

\section{References}

Ajzen, I. (1991). The theory of planned behavior. Organizational Behavior and Human Decision Process, 50, 179-211.

Alam, S. S., \& Sayuti, N. M. (2011). Applying the Theory of Planned Behavior (TPB) in halal food purchasing. International Journal of Commerce and Management, 21(1), 8-20. http://doi.org/10.1108/09574090910954864. 
Andi, N., Sutrisno, T., Rosidi, R., \& Roekhudin, R (2018). Determinants of tax compliance: theory of planned behavior and stakeholder theory perspective. Problems and Perspectives in Management, 16(4): 395-407.

Armenakis, A. A., Harris, S. G., \& Mossholder, K. W. (1993). Creating readiness for organizational change. Human Relations, 46(6), 681-703. http://doi.org/10.1177/001872679304600601

Azman, F. M. N., \& Bidin, Z. (2015). Zakat compliance intention behavior on saving. International Journal of Business and Social Research, 5(1), 118-128.

Bartunek, J. M., Rousseau, D. M., Rudolph, J. W., \& DePalma, J. A. (2006). On the Receiving End. The Journal of Applied Behavioral Science, 42(2), 182-206. http://doi.org/10.1177/0021886305285455

Bettencourt, L. A., \& Brown, S. W. (2003). Role stressors and customer-oriented boundaryspanning behaviors in service organizations. Journal of the Academy of Marketing Science, 31(4), 394-408. http://doi.org/10.1177/0092070303255636

Bidin, Z., \& Idris, K. M. (2007). A Confirmatory Analysis of Zakah Compliance Behavioural Intention on Employment Income. Malaysian Management Journal, 11(1), 103-114.

Bidin, Z., Idris, K. M., \& Shamsudin, M. F. (2009). Predicting compliance intention on Zakah on employment income in Malaysia: An application of Reasoned Action Theory. Journal Pengurusan, 28, 85-102.

Bidin, Z., \& Shamsudin, F. M. (2014). Using theory of reasoned action to explain taxpayer intention to comply with goods and services tax (GST). International Journal of Business and Social Science, 5(1), 131-139. http://doi.org/10.5829/idosi.mejsr.2013.17.03.12167

Bidin, Z., Shamsudin, F. M., Shalihen, M. S., \& Zainudin, M. O. (2011). Factors influencing intention to comply with local sales tax in Malaysia. SSRN Electronic Journal, 1-13. http://doi.org/10.2139/ssrn.1867923

Blanchard, C. M., Courneya, K. S., Rodgers, W. M., Daub, B., \& Knapik, G. (2002). Determinants of exercise intention and behavior during and after phase 2 cardiac rehabilitation: An application of the theory of planned behavior. Rehabilitation Psychology, 47(3), 308-323. http://doi.org/10.1037/0090-5550.47.3.308

Bobek, D. D., \& Hatfield, R. C. (2003). An investigation of the Theory of Planned Behavior and the role of moral obligation in tax compliance. Behavioural Research in Accounting, 15, 13-38.

Bobek, D., Hatfield, R., \& Wentzel, K. (2007). An investigation of why taxpayers prefer refunds: A theory of planned behavior approach. The Journal of the American Taxation Association, 29(1), 93-111.

Carswell, A. D. \& Venkatesh, V. (2002). Learner outcomes in an asynchronous distance education environment. International Journal of Human-Computer Studies, 56(5), 475494.

Chatzisarantis, N. L. D., \& Hagger, M. S. (2005). Effects of a brief intervention based on the Theory of Planned Behavior on leisure-time physical activity participation. Journal of Sport and Exercise Psychology, 27(4), 470-487.

Cheon, J., Lee, S., Crooks, S. M., \& Song, J. (2012). Computers \& Education An investigation of mobile learning readiness in higher education based on the theory of planned behavior. Computers \& Education, 59(3), 1054-1064. http://doi.org/10.1016/j.compedu.2012.04.015

Cohen, J. (1988). Statistical power analysis for the behavioral sciences (2nd ed.). Hillsdale, NJ: Erlbaum.

Evans, Chris. Diminishing Returns: The Case for Reduced Annual Filing for Personal Income Taxpayers in Australia. Australian Tax Review 33 (2004): 168-181. 
Fishbein, M., \& Ajzen, I. (1975). Belief attitudes intention and behavior: An introduction to theory and research. Califonia: Addison-Wesely Publishing Company. Retrieved from http://people.umass.edu/aizen/f\&a1975.html

Hadi, A., \& Safizal, M. (2016). Public acceptance and compliance on goods and services tax (gst) implementation: A case study of Malaysia. Asian Journal of Social Sciences \& Humanities, 5(1), 1-12.

Hair, J. F., Anderson, R. E., Tatham, R. L., \& Black, W. C, (1998). Multivariate Data Analysis (ed. 5). New Jersey: Prentice Hall.

Ibrahim, I. \& Pope, J. (2011). The viability of a pre-filled income tax return system for Malaysia. The Journal of Contemporary Issues in Business and Government, 17(2), 85101.

Inland Revenue Board of Malaysia. (2016). Annual Report 2015: Inland Revenue Board of Malaysia.

Javadi, M. H. M., Dolatabadi, H. R., Nourbakhsh, M., Poursaeedi, A. \& Asadollahi, A. R. (2012). An analysis of factors affecting on online shopping behavior of consumers. International Journal of Marketing Studies, 4(5), 81.

Johnson, J. W. (1996). Linking employee perception of service climate to customer satisfaction. Personnel Psychology, 49(831-851).

Kalafatis, S. P., Pollard, M., East, R., \& Tsogas, M. H. (1999). Green marketing and Ajzen's theory of planned behaviour: A cross-market examination. Journal of Consumer Marketing (Vol. 16). http://doi.org/10.1108/07363769910289550

Kolvereid, L., \& Isaksen, E. (2006). New business start-up and subsequent entry into selfemployment. Journal of Business Venturing, 21(6), 866-885. http://doi.org/10.1016/j.jbusvent.2005.06.008

Krueger, N. F., \& Carsrud, A. L. (1993). Entrepreneurial intentions: Applying the theory of planned behaviour. Entrepreneurship \& Regional Development, 5(4), 315-330. http://doi.org/10.1080/08985629300000020.

Lu, C.-T., Huang, S.-Y. \& Lo, P.-Y. (2010). An empirical study of on-line tax filing acceptance model: Integrating TAM and TPB. African journal of business management, 4(5), 800810.

Madden, T. J., Ellen, P. S., \& Ajzen, I. (1992). A comparison of the theory of planned behavior and the theory of reasoned action. Personality and Social Psychology Bulletin, 18, 3-9

Moorthy, M. K., Samsuri, A. S. B., Hussin, S. B. M., Othman, M. S. B. \& Chelliah, M. K. (2014). E-Filing behaviour among academics in Perak State in Malaysia. Technology and Investment, 5(02), 79.

Mueller, F., Jenny, G. J., \& Bauer, G. F. (2012). Individual and organizational health-oriented readiness for change. International Journal of Workplace Health Management, 5(3), 220-236. http://doi.org/http://dx.doi.org/10.1108/MRR-09-2015-0216

Nishimura, J. S., \& Tristan, O. M. (2011). Using the theory of planned behavior to predict nascent entrepreneurship. Academia, Revista Latinoamericana de Administration, 46, $55-71$.

Organisation for Economic Co-operation and Economic Development. (2006). Using third party information reports to assist taxpayers meet their return filing obligationsCountry experiences with the use of pre-populated personal tax returns. Paris: OECD.

Saad, N. (2011). Fairness perceptions and compliance behaviour: Taxpayers' judgments in self-assessment environments. University of Canterbury.

Saad, R. A., \& Haniffa, R. (2014). Determinants of zakah (Islamic tax) compliance behavior. Journal of Islamic Accounting and Business Research, 5(2), 182-193. http://doi.org/10.1108/09574090910954864 
Schneider, B., \& Bowen, D. E. (1985). Employee and customer perceptions of service in banks: Replication and extension. Journal of Applied Psychology, 70(3), 423-433.

Schneider, B., \& Bowen, D. E. (1993). The service organization: Human resources management is crucial. Organizational Dynamics, 21, 39-52.

Vakola, M. (2013). Multilevel readiness to organizational change: A conceptual approach. Journal of Change Management, 13(1), 96-109. http://doi.org/10.1080/14697017.2013.768436.

Venkatesh, V. \& Morris, M.G. (2000). Why don't men ever stop to ask for directions? Gender, social influence and their role in technology acceptance and usage behavior. MIS Quarterly, 24(1), 115-139.

Venkatesh, V. \& Davis, F. (2000). A theoretical extension of the technology acceptance model: four longitudinal field studies. Management Science, 46(2), 186-204.

$\mathrm{Wu}, \mathrm{I}$. L. \& Chen, J. L. (2005). An extension of trust and TAM model with TPB in the initial adoption of on-line tax: an empirical study. International Journal of Human-Computer Studies, 62(6), 784-808. 